\title{
Fetal Body Weight
}

National Cancer Institute

\section{Source}

National Cancer Institute. Fetal Body Weight. NCI Thesaurus. Code C124479.

An estimate or direct measurement of the heaviness of a fetus. 